\title{
Komposisi dan Kelimpahan Fitoplankton di Perairan Pandansari, Desa Kaliwlingi, Kabupaten Brebes, Jawa Tengah
}

\author{
Siti Aminah*, Ria Azizah Tri Nuraini, Ali Djunaedi \\ Departemen IImu Kelautan, Fakultas Perikanan dan Ilmu Kelautan, Universitas Diponegoro \\ Jl. Prof H.Soedharto S H, Tembalang, Semarang, Jawa Tengah 50275 Indonesia \\ ${ }^{*}$ Corresponding author, e-mail : sitiaminahofficial1007@gmail.com
}

\begin{abstract}
ABSTRAK : Fitoplankton merupakan dasar dari rantai makanan (primary producer) di perairan. Fitoplankton juga memiliki fungsi lain yaitu sebagai bioindikator untuk mengevaluasi kualitas dan tingkat kesuburan perairan. Keberadaan fitoplankton sangat penting karena mendukung seluruh kehidupan biota laut lainya. Tujuan penelitian ini adalah untuk mengetahui struktur komunitas fitoplankton dan kualitas perairan di sekitar ekowisata "Dewi Mangrove sari" berdasarkan kelimpahan dan keanekargaman fitoplankton. Penelitian ini di laksanakan pada tanggal 26 Juni 2018 dan 7 November 2018. Penelitian ini dilakukan di sekitar ekowisata mangrove "Dewi Mangrove Sari" Pandansari, Desa Kaliwlingi, Kabupaten Brebes, Jawa Tengah, dengan 3 stasiun dan 3 pengulangan pengambilan sampel. Metode yang digunakan dalam penelitian ini adalah metode deskriptif, sedangkan dalam penentuan titik lokasi pengambilan sampel fitoplankton menggunakan metode purposive sampling. Hasil dari penelitian ini ditemukan 4 dari 22 genus yaitu, Bacillariophycea dengan 15 genus, Dynophyceae dengan 5 genus, Cyanophyceae dengan1 genus dan Crysophyceae ditemukan 1 genus. kelimpahan fitoplankton sebesar 42.555,67 Ind/L pada Bulan Juni 2018 dan 44.072,17 Ind/L untuk bulan November termasuk dalam kondisi kesuburan tinggi (Eutrofik). Indeks keanekaragaman $\left(H^{\prime}\right)$ berkisar antara 1,91 - 2,57, indeks keseragaman (e) berkisar antara 0,65-0,84, indeks dominasi (C) berkisar antara 0,13-0,18. Kesimpulan dari penelitian ini indeks keanekaragaman di perairan sekitar ekowisata "Dewi Mangrove Sari" Pandansari, Desa kaliwlingi, Kabupaten Brebes, Jawa tengah termasuk dalam kategori tinggi dan tidak ada dominasi. Perairan sekitar ekowisata "Dewi Mangrove Sari" cukup stabil dan persebaran individu pada setiap genus cukup merata dan tidak ada jenis yang mendominasi.
\end{abstract}

Kata Kunci : Fitoplankton; Struktur Komunitas; Brebes

\section{Composition and Abundance of Phytoplankton in Pandansari Waters, Kaliwlingi Village, Brebes, Central of Java}

ABSTRACT: Phytoplankton are the basis of the food chain (primary producer) in water. Phytoplankton also has another function, namely as a bio-indicator to evaluate the quality and level of water fertility. The existence of phytoplankton is very important because it supports all other marine life. The purpose of this study was to determine the structure of the phytoplankton community and the quality of the waters around the ecotourism "Dewi Mangrove sari" based on the abundance and diversity of phytoplankton. This research was carried out on 26 June 2018 and 7 November 2018. The research was conducted around the Pandansari "Dewi Mangrove Sari" mangrove ecotourism, Kaliwlingi Village, Brebes Regency, Central Java, with 3 stations and 3 sampling repeats. The method used in this research is descriptive, while in determining the location of phytoplankton sampling locations using a purposive sampling method. The results of this study found 4 out of 22 genera namely, Bacillariophycea with 15 genera, Dynophyceae with 5 genera, Cyanophyceae with 1 genus and Crysophyceae found 1 genus. Phytoplankton abundance of 42,555.67 Ind / L in June 2018 and 44,072.17 Ind / L for November included in conditions of high fertility (Eutrophic). Diversity index $\left(H^{\prime}\right)$ ranged from 1.91 to 2.57 , uniformity index (e) ranged from 0.65 to 0.84 , dominance index $(C)$ ranged from 0.13 to 0.18 . It can be concluded that the diversity index in the waters around Pandansari's "Dewi Mangrove Sari" ecotourism, Kaliwlingi Village, Brebes Regency, Central Java is included in the high category and there is no dominance. The 
waters around the ecotourism "Dewi Mangrove Sari" are quite stable and the distribution of individuals in each genus is quite evenly distributed and no species dominates.

Keywords: Phytoplankton; Structure community; Brebes

\section{PENDAHULUAN}

Brebes merupakan sebuah kabupaten di Jawa Tengah yang letaknya berada di pesisir Utara Jawa (Pantura), sehingga kedudukannya lebih dekat dengan perairan laut khususnya di beberapa Kecamatan antara lain Kecamatan Brebes, Kecamata Wanasari, Kecamatan Losari, dan Kecamatan Tanjung. Kabupaten Brebes diharapkan mampu memanfaatkan berbagai potensi yang dimilikinya, sehingga dapat mengembangkan daerahnya sendiri. Potensi yang dapat dikembangkan di wilayah Brebes adalah sektor pariwisata, khususnya obyek wisata hutan mangrove. Obyek wisata hutan mangrove yang saat ini berkembang adalah wisata hutan mangrove Pandansari (Dewi Mangrove Sari) yang terletak di Desa Kaliwlingi Kecamatan Brebes. Obyek wisata hutan mangrove tterbentuk setelah ada kegiatan rehabilitasi mangrove yang dimulai sejak tahun 2005. Wilayah Kabupaten Brebes megalami abrasi seluas 650,54 ha pada tahun 2000-2008 (Dinas Perencanaan pembangunan penelitian dan pengembangan daerah Kabupaten Brebes, 2018). Dampak positif adanya rehabilitasi adalah adanya penambahan lahan mangrove seluas 815,76 ha pada tahun 2008. Menurut Annisa et al. (2019), menambahkan bahwa luas keseluruhan hutan mangrove di Desa Kaliwlingi pada tahun 2008 adalah 48.42 ha dan pada tahun 2013 bertambah 101.25 ha sehingga luasnya menjadi 149.67 ha.

Kegiatan rehabilitasi ini di manfaatkan dengan menjadikan lokasi tersebut sebagai daerah ekowisata mangrove. Kegiatan ekowisata antara lain berkeliling lokasi ekowisata menggunakan speedboat, penggunjung juga dapat melihat keanekaragaman mangrove. Aktivitas pengunjung yang berkeliling di sekitar ekowisata mangrove diduga dapat menyebabkan dampak buruk untuk kualitas air dan diduga menyebabkan perubahan struktur dan komunitas biota di dalamnya yang diantaranya adalah fitoplankton.

Fitoplankton merupakan produsen primer yang sangat penting dalam menunjang kehidupan organisme lainya, fitoplankton akan terpengaruh seiring terjadinya perubahan kualitas perairan. Keberadan fitoplankton di suatu perairan dapat memberikan informasi mengenai kualitas perairan (Thoha, 2004). Fitoplankton juga sebagai bioindikator suatu perairan untuk mengevaluasi kualitas dan kesuburan perairan (Wetzel, 1983).Tujuan penelitian ini adalah untuk mengetahui struktur komunitas fitoplankton dan kualitas perairan di sekitar ekowisata "Dewi Mangrove sari" berdasarkan kelimpahan dan keanekargaman fitoplankton.

\section{MATERI DAN METODE}

Penelitian dilakukan pada bulan Juni dan November 2018 di Perairan Sekitar Ekowisata "Dewi Mangrove Sari" Pandansari Desa Kaliwlingi Kabupaten Brebes Jawa Tengah. Metode penelitian yang digunakan adalah metode deskriptif yaitu metode dengan tujuan untuk mengetahui gambaran suatu objek pengamatan dan dapat menjelaskan perkembangan yang terjadi pada kondisi pengamatan (Hadi, 2004). Pengambilan sampel ditentukan dengan metode purposive sampling yaitu pemilihan sekelompok obyek berdasarkan atas ciri-ciri yang sudan diketahui sebelumnya (Hadi, 2004). Pengambilan sampel fitoplankton diulangi sebanyak 3x pada setiap stasiun dengan menggunakan plankton net yang memiliki diameter $21 \mathrm{~cm}$ dan mesh size $37 \mu \mathrm{m}$. Pengambilan sampel fitoplankton dilakukan dengan cara ditarik horizontal menggunakan kapal nelayan (Hasrun et al., 2013). Pengukuran parameter lingkungan yang meliputi salinitas, nutrient, suhu, kecerahan, $\mathrm{pH}$, DO dilakukan pada saat pengambilan sampel secara in situ di lokasi penelitian (Gambar 1). Sampel air juga doambil sebanyak $600 \mathrm{ml}$ untuk parameter fosfat dan nitrat dengan botol gelap.

Kelimpahan fitoplankton dinyatakan dalam individu per liter. Kelimpahan fitoplankton dikalkulasii dengan menggunakan rumus (Arinardi et al., 1997). Indeks Keanekaragaman (H') menurut Shannon-Weiner (Meiriyani et al., 2011) Kisaran Indeks Keanekaragaman adalah sebagai 
berikut : $0-1=$ kategori rendah; $2-3=$ kategori sedang; $>3=$ kategori tinggi Keseragaman adalah penyebaran individu antar spesies atau genus yang berbeda dan diperoleh dari hubungan antara keanekaragaman $\left(H^{\prime}\right)$ dengan keanekaragaman maksimalnya (Odum, 1993). Indeks keseragaman dapat dihitung dengan rumus dari Basmi (1997). Menurut Odum (1993), besarnya indeks keseragaman berkisar $0-1$ sebagai berikut: $e>0,6=$ Keseragaman jenis tinggi; $0,6=e=0,4=$ Keseragaman jenis sedang; e $<0,4=$ Keseragaman jenis rendah Indeks Dominansi digunakan untuk mengetahui sejauh mana suatu spesies atau genus mendominasi kelompok lain. Metode perhitungan yang digunakan adalah rumus indeks dominansi Simpson (Odum, 1993). Kriteria indeks dominansi menurut Odum (1993) adalah sebagai berikut: $0<\mathrm{C}=0,5=$ Tidak ada genus yang mendominasi; $0,5<\mathrm{C}<1=$ Terdapat genus yang mendominasi.

\section{HASIL DAN PEMBAHASAN}

Berdasarkan hasil penelitian yang dilakukan dalam 3 titik di perairan Pandansari desa Kaliwlingi Kabupaten Brebes di ketahui bahwa komposisi fitoplankton yang di temukan di lokasi terdiri dari 4 kelas berjumlah 22 genera yang terdiri dari kelas Bacillariophyceae (15 genera), Dinophyceae (5 genera), Cyanophyceae (1 genera) dan Crysophyceae (1 genera) pada bulan Juni 2018. Komposisi fitoplankton pada bulan November 2018 yaitu terdiri 4 kelas berjumlah 21 genera yang terdiri dari kelas Bacillariophyceae (15 genera), Dinophyceae (5 genera) dan Cyanophyceae (1 genera) (Gambar 2.).

Hasil pengukuran rata-rata kualitas air didapatkan data sebagai berikut : bulan Juni 2018 memiliki suhu $26{ }^{\circ} \mathrm{C}-27,9^{\circ} \mathrm{C}$, salinitas 6 ppt-31ppt, pH berkisar antara 7-8, kecerahan berkisar antara 0,65m-1 m, dan DO berkisar antara 3,9-4 mg/l, sedangkan pada Bulan November 2018 memiliki suhu berkisar antara $28{ }^{\circ} \mathrm{C}-29{ }^{\circ} \mathrm{C}$, salinitas $8 p p t-33 \mathrm{ppt}$, pH berkisar antara 7-9, kecerahan berkisar antara 0,34 m-0,97m dan DO berkisar antara 4-6,2 mg/l. Kandungan nitrat pada bulan Juni adalah 0,77 mg/l, dan pada bulan November 2018 sebesar 0,78 mg/l. Kandungan phospat pada bulan Juni 2018 adalah sebesar 0,084 mg/l . sedangkan pada bulan November 2018 adalah 0,035 (Tabel 1.). Hasil penelitian menggambarkan bahwa jumlah genus fitoplankton yang ditemukan lebih sedikit jika dibandingkan dengan hasil penelitian Wiyarsih (2017) menemukan 34 genera fitoplankton dari kelas yang sama. Jumlah fitoplankton yang sedikit diduga karena nilai curah hujan yang rendah. Curah hujan yang tinggi menyebabkan melimpahnya nutrient seperti nitrat dan fosfat di perairan (Meirinawati dan Muchtar, 2017). Hai ini disebabkan karena teraduknya dasar perairan sehingga terangkatnyanutrient seperti nitrat dan fosfat kepermukaan, sehingga menjadi lebih subur.
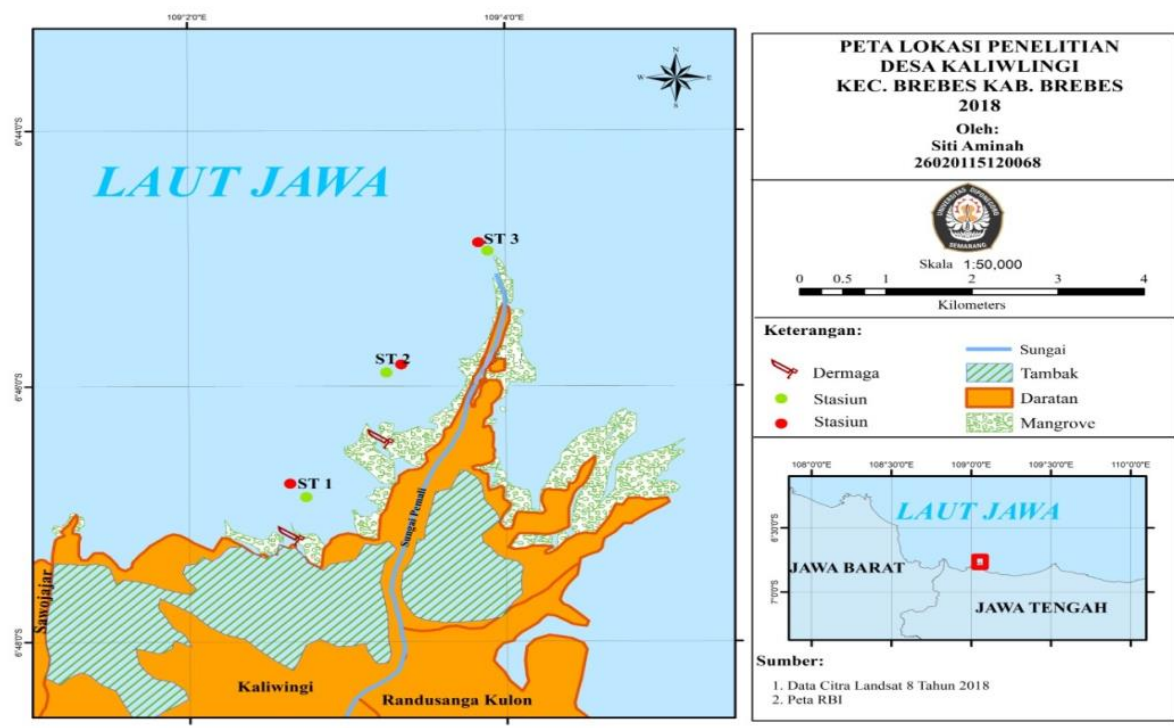

Gambar 1. Peta Lokasi Pengambilan Sampel di Perairan Sekitar Ekowisata "Dewi Mangrove Sari" Pandansari, Desa Kaliwlingi Kabupaten Brebes, Jawa Tengah. 
Tabel 1. Hasil Pengukuran Parameter Lingkungan di Perairan Pandansari Desa Kaliwlingi, Brebes Jawa tengah

\begin{tabular}{lcccccccl}
\hline \multirow{3}{*}{ Parameter } & \multicolumn{3}{c}{ Kaliwlingi } & \multicolumn{3}{c}{ Sawojajar } & \multirow{2}{*}{ Hasil } & \multirow{2}{*}{ Pustaka } \\
\cline { 2 - 6 } & \multicolumn{3}{c}{ Stasiun } & \multicolumn{3}{c}{ Stasiun } & \\
\cline { 2 - 6 } & SW I & SW II & SW III & SW I & SW II & SW III & & \\
\hline Suhu (C $\left.{ }^{\circ}\right)$ & 27,9 & 27,7 & 26,2 & 29,4 & 29,3 & 28,1 & $20-35$ & (Dawes, 1981) \\
Salinitas (ppt) & 31 & 30 & 6 & 33 & 24 & 8 & $25-32$ & (Nyabakken,1992) \\
Kecerahan (m) & 1,06 & 0,97 & 0,65 & 0,97 & 0,54 & 0,34 & $0-250$ & (Odum, 1993) \\
DO (mg/L) & 3,97 & 4,0 & 3,9 & 5,3 & 4,0 & 6,2 & $1-6$ & (Nyabakken,1992) \\
Ph & 8 & 8,5 & 7 & 9 & 8,2 & 7 & $6,5-8$ & (Nyabakken, 1992) \\
Nitrat (mg/l) & 0,8 & 0,796 & 0,714 & 0,567 & 0,748 & 1,051 & $0,9-3,5$ & (Haryadi dan Hadiyanto 2012) \\
Phospat (mg/l) & 0,031 & 0,215 & 0,006 & 0,065 & 0,034 & 0,006 & $0,09-1,8$ & (Makcethum, 1969) \\
\hline
\end{tabular}

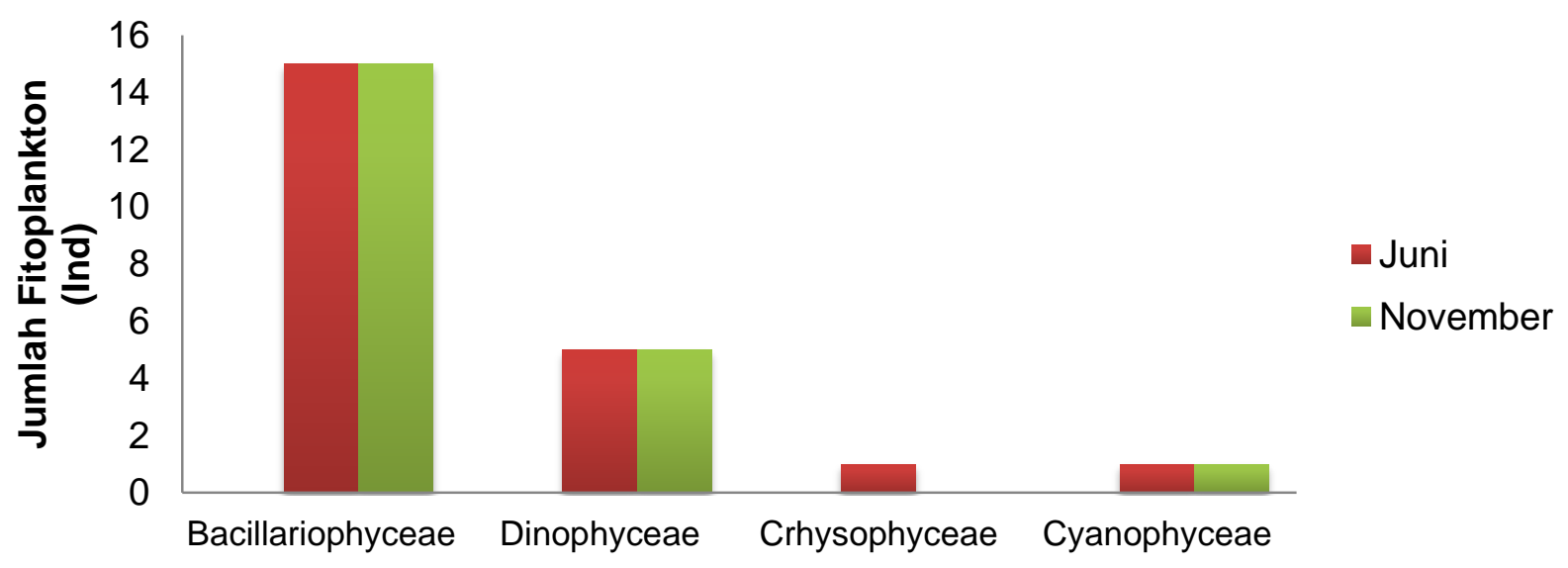

Gambar 2. Komposisi fitoplankton di Perairan Sekitar Ekowisata "Dewi Mangrove Sari" Pandansari, Desa Kaliwlingi Kabupaten Brebes, Jawa Tengah.

Berdasarkan hasil yang ditemukan, secara umum genus Coscinodiscus (kelas Bacillariophyceae) merupakan genus yang paling sering ditemukan di lokasi penelitian. Genus tersebut banyak ditemukan di perairan karena daya adaptasi salinitas yang lebih baik dan mampu bereproduksi dengan cepat (Odum, 1971). Menurut Madinawati (2012), tingginya kelimpahan Bacillariophyceae disebabkan karena organisme ini dominan ditemukan di perairan terbuka.

Komposisi fitoplankton di bulan Juni 2018 berjumlah 22 genera, sedangkan pada bulan Novemer 2018 berjumlah 21 genera. Bedasarkan hasil yang ditemukan genus yang paling banyak dijumpai pada bulan Juni dan November 2018 adalah Coscinodiscus dan Pleurosigma. Hal ini karena perairan tersebut mempunyai kandungan nitrat $0,77 \mathrm{mg} / \mathrm{l}$ dan fosfat $0,084 \mathrm{mg} / \mathrm{l}$ pada bulan Juni dan pada Bulan November adalah nitrat $0,78 \mathrm{mg} / \mathrm{l}$ dan fosfat $0,035 \mathrm{mg} / \mathrm{l}$, yang cukup baik genus Coscinodiscus dan pleurosigma, juga sangat membutuhkan nutrient seperti nitrat dan fosfat untuk menunjang pertumbuhannya selain itu mampu bertahan pada perairan yang memiliki intensitas cahaya yang sedikit, dan salinitas yang rendah. Area penelitian terdapat muara sungai besar yaitu Sungai Pemali serta curah hujan yang cukup tinggi yang menjadikan perairan mempunyai kandungan nutrien seperti fosfat cukup tinggi.

Rata-rata Kelimpahan fitoplankton di bulan Juni sebesar 42.555,67 sel/liter, sedangkan November sebesar 44.072,17 sel/liter. Tingginya kelimpahan di area ini diduga karena curah hujan bulan Juni 2018 yang lebih sedikit dari bulan November 2016. Data BMKG menunjukkan curah hujan sebesar $400 \mathrm{~mm}$ pada bulan Juni 2018 dan $480 \mathrm{~mm}$ bulan November 2018. Curah hujan yang tinggi menyebabkan perairan lebih banyak mendapatkan pasokan air tawar yang berasal dari sungai maupun air hujan. 
Kelimpahan fitoplankton di bulan November lebih besar dibandingkan bulan Juni 2018 (Gambar 3 ). Selain faktor curah hujan yang dapat mempengaruhi pertumbuhan fitoplankton, juga jumlah nutrient seperti nitrat dan fosfat dimana kandungan nitrat pada bulan Juni adalah 0,78 mg/l dan fosfat $0,084 \mathrm{mg} / \mathrm{l}$, yang kurang mendukung untuk kehidupan dan laju pertumbuhan fitoplankton, aktivitas pengerukan di area ini juga dapat mempengaruhi penetrasi cahaya matahari dalam perairan. Hal ini didukung pernyataan Romimohtarto dan Juwana (2007), bahwa laju pertumbuhan maksimum fitoplankton akan mengalami penurunan bila perairan berada pada kondisi ketersediaan cahaya matahari yang rendah.

Kelimpahan rata-rata setiap genus fitoplankton tertinggi secara umum adalah genus Coscinodiscus, Rhizosolenia, dan Pleurosigma yang selalu ditemukan pada setiap stasiun pengambilan sampel fitoplakton. Salah satu penyebab tingginya kelimpahan suatu genus pada perairan yaitu ada beberapa faktor yang mendukung pertumbuhan fitoplankton secara signifikan yaitu zat hara seperti nitrat dan fosfat, karena genus dari kelas fitoplankton tertentu sangat menyukai dan bergantung pada kadar zat hara tersebut. Setiap spesies salam komunitas mempunyai daya toleransi tertentu terhadap parameter lingkungan, maka akan terdapat daerah peralihan antara komunitas yang berdampingan dimana spesies secara alamiah. Nontji (1993), menyebutkan bahwa Rhizosolenia merupakan genera diatom yang seringdijumpai di perairan pantai Laut Jawa selain Skeletonoma, Chaetoceros dan Bacteriastrum Sebagai gambaranya dikatakan pula bahwa dalam menghadapi kondisi lingkungan yang kurang menguntungkanatau buruk bagi kehidupanyya dan apabila kondisi perairan telah membaik maka geus dari kelas tersebut akan tumbuh dengan baik kembali. Kisaran $\mathrm{pH}$ optimum untu pertumbuhan dan perkembangan Rhizosolenia berkisar antara 7.5-8.0. Hidup pada suhu antara $6-29^{\circ} \mathrm{C}$ dan kisaran suhu optimum $25-27^{\circ} \mathrm{C}$, kisaran salinitas 7-39 00/0 dan kisaran salnitas optimum 33-36 00/0.

Menurut Nybakken (1992), bahwa indeks keanekaragaman suatu komunitas mempunyai nilai tinggi menunjukkan bahwa ekosistem di daerah tersebut memiliki lingkungan yang seimbang, apabila nilai keanekaragaman rendah menunjukkan ekosistem perairan tersebut dalam keadaan tidak stabil dan kurang mendukung kehidupan biota. Nilai keanekaragaman pada bulan Desember di area Plawangan menunjukkan nilaitertinggi sebesar 2,32 (Gambar 6). Nilai tersebuttermasuk kategori sedang. Indeks Keanekaragaman Fitoplankton selama penelitian di Perairan Pandansari Desa Kaliwlingi Kabupaten Brebes Jawa Tengah pada bulan Juni 2018 dan November 2018 berkisar antara 1,91-2,38 dan 2,36-2,45. Nilai tersebut termasuk kategori rendah. Halini menunjukkan bahwa di area tersebutmempunyai kestabilan komunitas yang sedang. Menurut Odum (1993), nilai indeks keanekaragaman yang sedang menunjukkan kestabilan perairan sedang.

Indeks keseragaman yang diperoleh selama penelitian berkisar antara 0,65-0,79 untuk bulan Juni 2018 dan 0,76-0,80 untuk bulan November 2018 yang menunjukkan kategori keseragaman tinggi $(e>0,6)$ mengacu pada Krebs (1985). Berdasarkan kisaran indeks keseragaman (e) Odum (1993), maka keseragaman populasi fitoplankton termasuk ke dalam kriteria tinggi. Hal ini

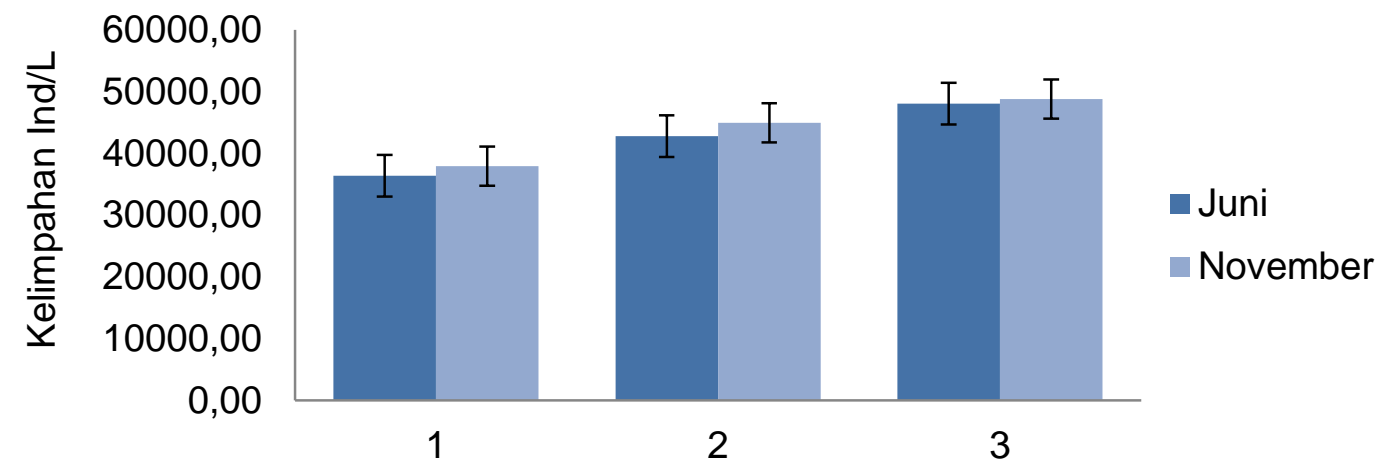

Gambar 3. Rata-rata Kelimpahan fitoplankton bulan Juni 2018 dan November 2018 di Perairan Sekitar Ekowisata "Dewi Mangrove Sari" Pandansari, Desa Kaliwlingi Kabupaten Brebes, Jawa Tengah.

menunjukan penyebaran individu adalah sama atau merata dan diduga ada kelimpahan genus tertentu yang relatif tinggi dibandingkan yang lainya. Indeks dominasi (D) fitoplankton selama 
penelitian berkisar antara 0,14-0,16 pada Bulan Juni dan 0,13-0,18 pada bulan November 2018 dan termasuk ke dalam kategori tidak ada jenis yang mendominasi $(0<D<0.5)$ mengacu pada Odum (1993). Hal ini mengambarkan bahwa tidak ada genus fitoplankton yang mendominasi di Perairan Pandansari Desa Kaliwlingi Kabupaten Brebes Jawa Tengah. Odum (1993) menyatakan nilai indeks dominasi berkisar antara 0 -1. Jika nilai indeks dominasi mendekati 0 , berarti tidak ada individu yang mendominasi, sebaliknya jika nilai indeks dominasi mendekasi 1 , maka ada individu yang mendominasi, indeks dominasi bersifat linear terhadap indeks keseragaman diartikan bahwa semakin besar indeks dominasi maka semakin tinggi indeks keseragaman.

\section{KESIMPULAN}

Fitoplankton yang ditemukan di lokasi terdiri dari 4 kelas fitoplankton berjumlah 22 genera yaitu dari kelas Bacillariophyceae (15 genera), Dynophyceae (5 genera), Cyanophyceae (1 genera) dan Crysophyceae (1 genera). Kelimpahan fitoplankton tergolong tinggi sehingga dapat diartikan perairan tersebut sangat subur. Indeks Keanekaragaman fitoplankton sedang, indeks keseragaman termasuk dalam kategori tinggi dan indeks dominasi tidak ada jenis yang mendominasi, sehingga perairan dapar di katakana cukup stabil dan tidak ada jenis yang mendominasi.

\section{UCAPAN TERIMA KASIH}

Artikel ini merupakan bagian dari skripsi yang berjudul "Struktur Komunitas Fitoplankton di sekitar Ekowisata 'Dewi Mangrove Sari” Pandansari, Desa Kaliwlingi, Kec.Brebes, Kab.Brebes, Jawa Tengah", untuk memperoleh gelar Sarjana Strata Satu Program Studi IImu Kelautan, Fakultas Perikanan dan IImu Kelautan Universitas Diponegoro.

\section{DAFTAR PUSTAKA}

Annisa, Y.N., Pribadi, R. \& Pratikto, I. 2019. Analisis Perubahan Luasan Hutan Mangrove Di Kecamatan Brebes Dan Wanasari, Kabupaten Brebes Menggunakan Citra Satelit Landsat Tahun 2008, 2013 dan 2018. Journal of Marine Research, 8(1):27-35.

Arinardi, O.H., Sutomo, A.B., Yusuf, S.A., Trimaningsih., Asnaryanti \& Riyono, S.H. 1997. Kisaran Kelimpahan dan Komposisi Plankton Predominan di Kawasan Timur Indonesia. LIPI, Jakarta.

Badan Perencanaan Pembangunan Penelitian dan Pengembangan Daerah; dan Dinas Penanaman Modal dan Perizinan Terpadu Saru Pintu. 2018. Pengembangan Ekowisata Hutan Mangrove Dukuh Pandansari Desa Kaliwlingi Kecamatan Brebes Kabupaten Brebes. Proposal Proyek Investasi.

Basmi, J. 1997. Terminologi dan Klasifikasi Zooplankton Laut. Institut Pertanian Bogor, Bogor.

Hadi, S. 1993. Metodologi Research. Jilid II. Yogyakarta. Andi Offset.

Hasrun, L., Ma'ruf, K., \& Salwiyah. 2013. Studi Biodiversitas Diatom Bentik pada Areal Mangrove di Perairan Kecamatan Kolono Kabupaten Konawe Selatan. Jurnal Mina Laut Indonesia, 2(06):35-47.

Haryadi, J. and Hadiyanto, H., 2012. Korelasi Nutrien Terlarut Dengan Struktur Komunitas Plankton Di Tambak Mangrove Blanakan, Kab. Subang. Jurnal Pengelolaan Sumberdaya Alam dan Lingkungan (Journal of Natural Resources and Environmental Management), 2(2), p.73.

Madinawati, M., 2012. Kelimpahan dan Keanekaragaman Plankton Di Perairan Laguna Desa Tolongano Kecamatan Banawa Selatan. Media Litbang Sulteng, 3(2):119123.

Meirinawati, H. \& Muchtar, M., 2017. Fluktuasi Nitrat, Fosfat dan Silikat di Perairan Pulau Bintan. Jurnal Segara, 13(3):141-148

Nybakken, J.W. 1992. Biologi Laut Suatu Pendekatan Ekologi. Penerbit PT. Gramedia, Jakarta.

Odum, E.P. 1993. Dasar dasar Ekologi. Edisi ke III. Diterjemahkan oleh Tjahjono, S. Gajah Mada University Press. Yogyakarta.

Romimohtarto, K, \& Juwana, S. 2007. Biologi laut. Penerbit Djambatan, Jakarta.

Wetzel, K. 1983. The Limnology. Morsby Company. London 